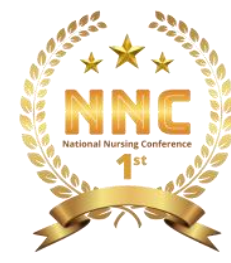

1St National Nursing CONFrence:

The Sustainable InNOVATION IN NuRSing EDUCATION

AND PRACTICE

DOI: https://doi.org/10.34305/nnc.v1i1.129

\title{
HUBUNGAN TINGKAT KESIAPAN DAN DUKUNGAN SUAMI DENGAN DEPRESI SELAMA KEHAMILAN PADA IBU HAMIL DI PUSKESMAS CIWARU KABUPATEN KUNINGAN TAHUN 2018
}

\author{
Russiska, Cecep Heriana, Maryana \\ Sekolah Tinggi Ilmu Kesehatan Kuningan Garawangi \\ russiska88@gmail.com
}

\begin{abstract}
ABSTRAK
Saat Kehamilan, perubahan hormon bisa mempengaruhi kimia otak yang berhubungan dengan depresi dan kecemasan pada ibu hamil. Depresi saat kehamilan merupakan gangguan mood sama dengan gangguan klinis. Depresi pada kehamilan disebabkan banyak hal, mulai dari perubahan hormon, perubahan kondisi fisik sampai dengan dukungan suami pada saat hamil. Tujuan penelitian untuk mengetahui hubungan tingkat kesiapan dan dukungan suami dengan depresi selama kehamilan pada ibu hamil di Puskesmas Ciwaru Kabupaten Kuningan Tahun 2018. Metode penelitian analitik dengan rancangan cross sectional. Teknik sampling menggunakan accidental dengan jumlah sampel sebanyak 52 responden. Hasil analisis univariat menunjukkan tingkat kesiapan ibu hamil yang tidak siap dengan kehamilannya sebanyak 31 responden $(59,6 \%)$, dan suami yang tidak mendukung sebanyak 27 responden (50,9\%). Analisis menggunakan uji chi-square diperoleh tingkat kesiapan menunjukkan $\rho$-value $=0,009$, dan dukungan suami menunjukkan $\rho$-value $=0,033$. Kesimpulannya terdapat hubungan yang signifikan antara tingkat kesiapan dan dukungan suami dengan depresi selama kehamilan. Diharapkan ibu hamil memeriksakan kesehatannya terlebih dahulu sebelum terjadi kehamilan, agar lebih siap pada saat hamil. Perlu adanya dukungan suami yang lebih ketika istrinya hamil karena ibu hamil sangat membutuhkan dukungan emosional serta dukungan fisik seperti penilaian, informasi dan finansial terutama pada saat masa kehamilan.
\end{abstract}

Kata Kunci: Depresi, Tingkat Kesiapan, Dukungan Suami.

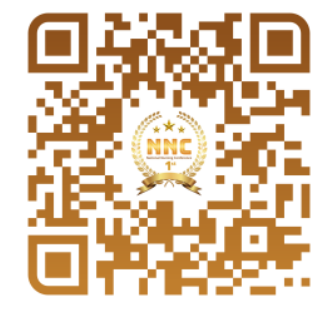

